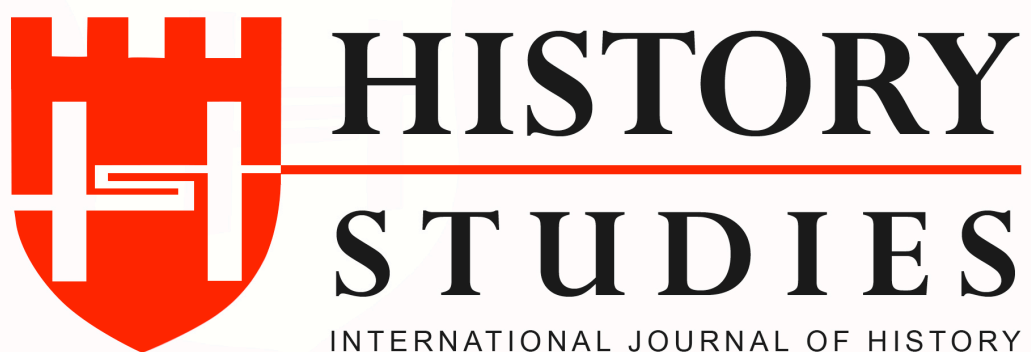

ISSN: 13094173 (Online) 1309 - 4688 (Print)

Volume 11 Issue 5, October 2019

DOI Number: 10.9737/hist.2019.779

Araștırma Makalesi

Makalenin Geliş Tarihi: 13.09.2019 Kabul Tarihi: 30.09.2019

Atıf Künyesi: Nedim İpek, “Göçü ve Göçmeni Anlamak”, History Studies, 11/5, Ekim 2019, s. 1575-1584.

\title{
Göçü ve Göçmeni Anlamak
}

\author{
To Understand Immigration and Migrant
}

\author{
Prof. Dr. Nedim Ípek \\ ORCID No: 0000-0001-9239-1333 \\ Ondokuz Mayls Üniversitesi
}

Özet

Göç, kişinin bulunduğu yerden bir başka yere gitme halidir. Bu durum zorlayıcı sebeplerle ortaya çıkabileceği gibi kişisel tercihlerle de olabilmektedir. Osmanlı Devleti'nin hâkimiyetindeyken bırakılan topraklardan bu şekilde kitlesel göçler yaşanmıştır. Bunların bazıları artık mensubu bulundukları yeni devlet dâhilinde yaşamak istemeyenlerin gerçekleştirdikleri göçler olmuştur. Bazıları ise ilgili devlet ile yapılan antlaşma gereğince zorunlu göçe tabi tutulmuşlardır. Her iki durumda da yaşadığ 1 toprakları terk etmek zorunda kalan insanların yaşadıkları travmaları kelimelerle anlatmak güçtür. Göçün yaşanılan yeri terk etmek hususundaki zorlukları, göç edilen yerde de devam etmiştir. Nitekim zorlayıcı nedenlerle anavatan olarak telakki edilen topraklara gelen bu insanlar zorluklar yaşamaya devam etmişlerdir. Terk ettikleri topraklarda maruz kaldıkları durumların benzerleri olmasa bile göç ettikleri yerde de öteki konumundadırlar. $\mathrm{Bu}$ ise onların mevcut toplum yapısına uyumlarını zorlaştırmışıı. Kafalarında mümkün olduğunda geri dönmek arzusunu uzun bir süre muhafaza etmelerinin bir nedeni de bu olabilir. Bu açıdan göçün nedenlerinin ortaya konması her zaman bütünü görmek açısından yeterli olmamaktadır. Bizzat göçenlerin hikayeleri, öncesi ve sonrası ile hissettikleri ayrıca değerlendirilmeye muhtaçtır. Bu çalışmada göçün gerçekleșme nedenleri üzerinde durulmuştur. Ayrıca göç öncesi ve sonrası süreçlerin genel bir değerlendirilmesi yapılmıştır. Göç edenlerin kendilerini ifadede yaşadıkları sıkıntıların dışında göçü bazı yönleri ile sadece buna maruz kalanların anlamlandırabileceğine işaret edilmiştir.

Anahtar Kelimeler: Göç, Göçmen, Mübadil, Mübadele

\begin{abstract}
Migration is the state of moving from one's place to another. This can be caused by compelling reasons or by personal reasons. In this way, there were mass migrations from the lands left under the rule of the Ottoman Empire. Some of these have been immigrants from those who do not want to live in the new state they belong to. Some have been subjected to forced migration in accordance with an agreement with the state concerned. In both cases, it is difficult to describe the traumas experienced by people who had to leave their lands. Difficulties of migration to leave place of residence continued in the place of migration. As a matter of fact, these people who came to the lands considered as homeland for compelling reasons continued to experience difficulties. Even if they are not the same as the situations in which they are exposed, they are also "other" where they migrate. This made it difficult for them to adapt to the existing social structure. This may be one reason why they have kept their desire to return for as long as possible in their minds. In this respect, it is not always sufficient to reveal the reasons of migration. The stories of the migrants themselves and their feelings before and after need to be evaluated separately. In this study, the reasons for the realization of migration are emphasized. In addition, a general evaluation of the pre- and post-migration processes was made. It
\end{abstract}


was pointed out that, apart from the difficulties experienced by the migrants in expressing themselves, some aspects of migration can only make sense to those who are exposed to it.

Key Words: Migration, Immigrant, Refugee, Population Exchange

"Kızım Senin Hocan Ne anlar Mübadeleden!"

Türk toplumu tarihi süreç içerisinde insanî değerlere önem vermiştir. Bu nedenle Türk toplumunun hâkim olduğu ülkelerde hemen tüm bireylere ve cemaatlere değerleri ile yaşama imkânı tanınmıştır. Oysa Osmanlı Devleti'nin terk ettiği coğrafyada kurulan ulus devletler özellikle Türk ve Müslümanlara değerleri ile yaşama imkânı tanımamışlardır. Çeşitli kısıtlamalar getirmişlerdir. $\mathrm{Bu}$ ise 1774 'den bugüne kadar Kırım, Kafkaslar, Balkanlar, Afganistan, Irak ve Suriye'den Anadolu'ya nüfus göçlerine sebebiyet vermiştir.

Göç kararını almak kolay olmasa gerek. Savaş ortamında "Geri ağalar geri Hıristiyanlar ile Türkler artık bir arada yaşamıyorlar" ifadesinden anlaşılacağı üzere toplumun etnik farklılık açısından ayrıştırılması, toplu katliama maruz kalacakları söylentisinin yaygınlaşması Türk toplumunda psikolojik bask1 oluşturmuştur. Psikolojik baskı veya bizzat yaşanan zulümler üzerine Türkler savaş ortamında göçmenlerin tanımlamasıyla "namusunu korumak için", "Türk gibi yaşamak için", "kimliğini korumak için, "Türk olarak başka bir dili kullanmayı kabullenmedikleri için", geri dönmek hayali ile yerini yurdunu terk etmeye karar verirler. 1951'de göç eden bir Bulgaristan muhaciri göç sebebini şu şekilde ifade etmektedir: Müslümanlığ kaybetmeyelim diyerek, peygamberimizin yolundan onun hicret ettiği gibi Müslümanliğı nerede yapacaksak oraya gittik”.

Bu sebeple göç kararı alınınca evin tüm odaları dualar okunarak dolaşılır, kapılar dua ile kilitlenir, mağazaların kepenkleri dualar ile indirilir ${ }^{1}$ ve göç kafilesine dahil olunurdu. Kafileler daha ziyade kadın, çocuk ve ihtiyarlardan oluşmaktaydı. Muhacirlerin çoğu, kocası askerde şehit düşmüş kadınlardı. Bunlar bir çocuğunu sırtına bağlamış, birini kucağına almış, diğerini önüne katmış esir olmamak, namusunu korumak, çocuklarını yaşatmak için göç kararı almış kadınlardı. ${ }^{2}$ Göçmen kadınların ifadesiyle "bilinmeyene yolculuğa çıkmışlardl.". Peki nereye gidilecektir? Kaynaklardan anlaşıldığı kadarıyla göçmen kendisini güvende hissedebildiği yere kadar gitmek ister. Türk bayrağının dalgalandığı yere kaçılacak veya göçülecektir. Bir göçmen sanki bu sorunun cevabını veriyordu konuşurken: "Trene bindik. Baktık ki trende Türkçe yazılar ve ay-yıldız. Öyle sevindik ki Türk trenine bindik diye. Camdan domuz sürüsü gördük. Bu domuzlar Türkiye'de ne arlyor dedik. Meğerse Yunanistan topraklarından geçiyormuşuz.".

Göç, psikolojik açıdan göç öncesi, göç süreci ve gö̧ sonrası olmak üzere üç evrede incelenebilir. Bu evrelerin psikolojik etkileri göç eden her kişi ve grup için oldukça farklıdır. Göçün psikolojik etkileri büyük ölçüde kişiye veya gruba özgüdür.

Göçmenin psikolojisini algılayabilmek için göç öncesi göç veren coğrafyanın sosyal ve siyasal yapısını, orada yaşanmışlıkları tespit edip değerlendirmek gerekir. Bu araştırma bizi göç sebepleri ile karşılaştırır. Göç öncesi dönemden kaynaklanan faktörler arasında göçün nedeni, kaybedilecek şeylerin çapı, derinliği çok önemlidir. Kişi hayatını, güvenliğini kurtarmak için bir yerden kaçmak zorunda kalırsa, hem bunun tehditlerle ve eziyetlerle yarattığ 1 travmayla hem de aniden, tamamen hazırlıksız bir şekilde yerinden yurdundan kopmanın getirdiği yükle uğraşmak zorunda kalır. Göç ederken geride bırakılanların, bir anlamda kaybedilenlerin boyutu

\footnotetext{
${ }_{1}^{1}$ Mevhibe Coşar, "Bir Kıyamet Provası: Göçe Sürgün Hayatlar”, Göç Dergisi,3/2, (Ekim 2016), s. 166- 174.
${ }_{2}^{2}$ Mevhibe Coşar, "Bir Kıyamet Provası: Göçe Sürgün Hayatlar”, Göç Dergisi,3/2, (Ekim 2016), s. 166- 174.

${ }^{1}$ Mevhibe Coşar, "Bir Kıyamet Provası: Göçe Sürgün Hayatlar", Göç Dergisi,3/2, (Ekim 2016), s. 166- 174.
${ }^{2}$ Mevhibe Coşar, "Bir Kıyamet Provası: Göçe Sürgün Hayatlar", Göç Dergisi,3/2, (Ekim 2016), s. 166- 174.
} 
da çok önemlidir. İnsana destek veren, onu koruyan güçlendiren ne kadar çok şey geride bırakılıyorsa, göçün psikolojik etkisi o kadar olumsuz olacaktır.

Göç, kişinin sevdiklerini, yakınlarını, çocukluğunun geçtiği ve kişiliğinin oluştuğu köyünü, kasabasını, yurdunu, yuvasını, evini, barkını, ahrete göç etmiş aile bireylerinin mezarlarını terk etmesi demektir. Bunlardan ne kadar çok fazlası geride bırakılıyorsa o kadar fazla risk faktörü var demektir.

Geride bırakılanların en önemlisi toplumun bir kısmıdır. Bunlar anne, baba, kardeş, dayı, teyze, amca, komşu olabilmektedir. Bu durumda ailenin parçalanması gündeme gelmektedir. Kitlesel göçler incelendiğinde kolayca tespit edilebileceği üzere göç sürecinde toplum top yekun göç etmez. Toplumun bir kısmı göç ederken diğer kısmı itici sebeplere rağmen vatanında yaşamayı sürdürmeye çalışır. Göç, ailelerin parçalanmasına da sebebiyet verir. Göçmen bu durumdan şu şekilde yakınır:

Gurbet elde ölenlerin

Çenesini kim bă̆lar

Ne anam var, ne babam var

Baş ucumda kim ă̆lar

Göç veren toplum zamanla küçülür. Küçülen topluluk varlığını korumakta en azından zorlanır. Batı Trakyalı Mehmet'e hitap eden türkü aslında göçü önlemeye çalışmak amacıyla yakılmıştır.

Daha 20 kulaçönce 500 bin kadardık,

Göç şarabı içe içe yüz bine düştük, bayıldık,

Gitme Mehmet Mehmet gitme!

Terk edilen yerlerdeki Türk toplumu asimile edilmeye çalışılır. Asimile yöntemlerinden birisi de isim değiştirmedir. Bir Bulgaristan göçmeni bu durumu şu dizelerle gündeme getirmekteydi:

Babam adımı koydu ezan ile

Kâfir değiştirdi silah ile

Annem ă̆ladı gözyaşı ile

Toplumun küçülmesi neticesi evlilik çağındaki kızlar evlenecek delikanlı bulamaz. Bu ortamda Müslüman kızların Hıristiyan gençlerle evlenme ihtimali gündeme gelir. Bu uzun vadede toplumsal kimliğin yok olması ile sonuçlanabilecektir. Müslüman kızların Hıristiyanlarla evlenmek zorunda kalması her şeye rağmen o ana kadar ocağını terk etmeyenleri göç kararı almaya iter ${ }^{3}$.

Henüz göç etmeyenlerin yaşadığı mahalle ve şehir mimari açıdan dönüşmeye başlar. Müslüman mahallelerinde göç eden Türklerin evlerine gayrimüslimler yerleşir. Beraberlerinde kültürel unsurlarını getirip yaşatırlar. Örneğin Üsküp el değiştirdiğinde Türk mahallesine yerleşen gayrimüslimler mevcut ahırlarda domuz da beslemekteydiler. Bu durum Türk sakinleri rahatsız eder. Bir göçmen kaleme aldığı hatıratında domuzun bastığı yere basmamak için sokakta sekerek yürüyorduk şeklinde bu hususa vurgu yapmaktadır. Bu durum türkü ve şiirlere de yansir.

\footnotetext{
${ }^{3} \mathrm{Bu}$ sadece Türk toplumuna özgü bir toplumsal tepki değildir. Örneğin Rus Kazakları Cumhuriyet döneminde evlenememe sebebiyle Türkiye'den göç edeceklerdir. Bkz. Z. F. Fındıkoğlu, Türkiye'de İslav Muhacirleri (19611962) Türkiye'deki Malakan ve Kazakların Rusya'ya Dönmeleri, İstanbul 1966, s. 37.
} 
Mihraplara haç asılmış. Ezanlar!

Susturulmuş güm güm ötüyor çanlar!

Camilerin minberleri yakılmış

Çizme ile çiğneniyor Kur'anlar!

Bu durumu Mehmet Akif de şu dizelerle aktarıyordu:

Ne felaket: Dönüversin de mesacit ahira

Hırvatın askeri tepsin çıkıp üstünde hora!

Bâri bir hâtıra kalsaydı şu toprakta diri...

Yer yarılmış, yere geçmişs şüheda türbeleri!

Aynı konu Ötme bülbül ötme, yaz bahar oldu başlıklı türküde şu dizelerle ifade edilmekteydi.:

Çeşmelerde abdest alınmaz oldu

Camilerde namaz kulinmaz oldu

Mamur olan yerler hep harap oldu

Aldı Nemçe bizim nazlı Budin'i.

Muhacir memleketi hayallerinde bıraktığ1 gibi yaşatır. Memleket deyince mezarlık, cami, mektep, hocanın sopasını hatırlar. Henüz göç etmeyenin böyle bir hayal kurma şansı bile yoktur. Çünkü köyü, kasabası veya şehri gittikçe yabancılaşmaktadır: Türk kültürünü yansıtan cami, mescit, hazire, mezarlıklar tedricen ortadan kalkar. Yerini park, katedral, kilise, batı mimari tarzıyla inşa edilmiş konutlar doldurur. Mahalle, sokak, köy isimleri değişir. Şehir isimlerinin de en azından telaffuzu değişir. Mevcut veya yeni inşa edilmiş kiliselerde çan sesleri yükselir. Ay yıldız damgalı sancak direklerinde yeni kurulan devletin bayrağı dalgalanmaya başlar.

Göç etmeyenler için günlük yaşamda değişiklikler olur. Her şeyden önce Osmanlı vatandaşı iken Yunan, Bulgar, Rus veya Sırp vatandaşıdır artık. Toplumsal statüsü millet-i hâkimeden azınlık statüsüne dönüşmüştür. Günlük yaşamını sürdürebilmek için resmî dili öğrenme zorunluluğu ile karşı karşıyadır. En azından resmî kurumlarla irtibat kurabilmek için Bulgarca, Sırpça, Rusça veya Yunanca kullanmak zorunda kalır. Şehrin ve devletin idarecileri artık Müslim ve Türk değildir. Millî günler değişmiştir. Balkan devletleri güçlerini arttırmak adına Türkleri ötekileştirme politikalarının şiddetini arttırırlar. 15 Temmuz 1935 tarihli Zaman gazetesinde Bulgaristan idarecileri için bunun önemli bir politika olduğu şu şekilde vurgulanmıştır: "Hakikaten Bulgarlar için Türk düşmanlı̆̆ maddî ve manevî bir azıktır. Bulgar çocuğu dünyaya gözünü açar açmaz Türk aleyhinde ninni dinler ve onunla uyur. Mektebe gider gitmez sinıfların duvarlarında "Beş süngüde bir Türk" resimlerini görür ve onları seyrede seyrede, Türk'ün aleyhinde bin bir yalanla dolu tarih ders kitabını okuya okuya büyür. Onun içindir ki en ufak Bulgar köylüsünden en büyük devlet adamına kadar her Bulgar'da Türk düşmanlığı bir ihtiyaç, bir iman, bir ülküdür. Bulgar her şeyi unutur, yalnız Türk düşmanlı̆̆ını unutmaz ${ }^{4}$. Karacaoğlan İndim seyran ettim Frengistan'l isimli şiirinde sanki bu coğrafyayı tanımlamaktaydı:

... Illleri var bizim ile benzemez,

... Dilleri var bizim dile benzemez,

... Dinleri var bizim dine benzemez,

... Başlarına siyah şapka giyerler,

... Beyleri var bizim beye benzemez,

${ }^{4}$ Zaman, 15 Temmuz 1935, No. 385 . 
...Vatan tutup bu yerlerde kalınmaz.

Göç veren sahalarda ulus devletler kurulur. Bu devletlerde askerlik yükümlülük esasına göre yapılmaktadır. Belirli yaş grubunda olanlar silâhaltına alınır. Müslim ve gayrimüslim aynı kazandan yemek yer. Aynı üniformayı giyer. Devletin karar vermesi halinde savaşa gider. Bu uygulamaları düşünmek bile herhalde kişide travma yaratır. Çözüm firar veya göç etmekte bulunur. Romanya söz konusu mahzurları ortadan kaldırmak adına Müslüman askerlerin şapka takma zorunluluğunu kaldırmış, Türk askerlerine Müslüman aşçılar tarafından pişirilen yemekleri ayrı kaplarda yeme imkanı sağlamış ve kışlalara mescit inşa etmiş, imam görevlendirmiştir. Ancak bu değişiklikler Romanya vatandaşı olup silâhaltına alınan Türk askerinin endişelerini gidermez. Peki savaşta karşı karşıya kalınırsa ne olacaktı? Hatırlamak gerekirse Birinci Dünya Savaşı'nda Osmanlı ve Romanya karşı cephelerde yer almışlardı. Burada Romanya ordusundaki Türk askerinin davranışı ne olmalıydı?

Muhtemelen bütün bu değişiklikler göç etmeyenlerde aidiyet krizi yaratmıştır. Her şeye rağmen ocağını tüttürmeye çalışan, vatanını terk etmemekte direnenler bu yeni ortamda yeni yaşam alanında kültürünü yaşatamamak, sosyal konumunu tayin edememek ve sosyal düzenini anlamlandıramamak gibi bir konuma düşer. Berger'e göre bu durum bireyin katlanamayacağ 1 tek acıdır. Bu savaş sonrası yeni göç dalgalarını tetikler.

Kırım'da, Romanya'da, Bosna'da geride kalanlar Hıristiyan bir ülkede Müslüman olarak yaşamanın dinen uygun olup olmadığını tartışır. İsmail Gaspıralı Kırım'da göçü durdurmaya yönelik faaliyetlerde bulunur. Göçü durdurmak adına hem Rus devlet adamlarını ve hem de Türk kamuoyunu ikna etmeye ve itidalli davranmaya davet eder. Göçün sürüp sürmemesi konusu Romanya Türk basınında da tartış1ır. Göç etmeye gerek yoktu. Göç geride kalanların önemsenemeyecek bir azınlığa düşmesine sebebiyet veriyordu. Bununla beraber göçü savunan yazılara da tesadüf edilmekteydi. Örneğin Hak Söz Gazetesi: "Göç bir köprüdür. Yüzlerce sene daha buralarda tutunmayı ve barınmayl gözümüze alsak bile en son bir halde sürünüp ve yuvarlanip gidilecektir 5 .

Göçü durdurmaya yönelik faaliyetlere rağmen özellikle Bulgaristan Türkleri firsatını bulduklarında göç etme psikolojisi içerisindedirler. Bulgaristan Türkleri için Bulgaristan'da mülk edinmek, "buz üstünde yapılan bir yatırım ve harcamadır." Türkiye'de kişiler körlük kefenlik parası biriktirirken, Bulgaristan'daki Türkler daha düne kadar her an sınır açılır ve göç edilir düşüncesi ile gelirlerinin büyük bir kısmını Türkiyecilik adı altında biriktirmekteydiler.

Muhacir ata toprağında ev, bark, bahçe, dükkan, tarla gibi gayrimenkullerini ve taşınabilir mal varlıklarını terk etmek zorunda kalır. Bir başka ifadeyle savaş ortamında gelenler o ana kadar biriktirdiklerini, birikimlerini terk etmişlerdir. Savaş sonrası gelenler görece mal varlıklarını tasfiye edip gelme imkânına sahiptirler. Ancak göç dalgasının kaçınılmaz olduğunu gören gayri Türkler söz konusu satış ilanlarına ilgi göstermez veya yok pahasına almaya çalışırlar. Kısacası göçmen daha göç yoluna çıktığında sıfırı tüketmiştir. Orada her şeyimiz vardl. Varlıklıydık. Buraya geldik. Hiçbir şeyimiz kalmadl. Ev yok, bark yok, mal yok, mülk yok. Daimi iskân sonrası tekrar sıfırdan işe başlamak durumunda kaldılar.

Muhacirlerin geride bıraktıkları en önemli unsur, yaşanmışlıkları, çocukluğu ve gençliğidir. Bir muhacir bu durumu şöyle vurgulamaktadır: Geride biraktıklarımızın ev, tarla ve toprağın yanı sıra doğup büyüdüğümüz kent, komşularımız olduğunu fark ettik. ... Evi, tarlayı, toprağı bedelleştirebilirsin belki ama doğduğumuz yerin havasını, suyunu nasıl bedelleştirebilirsin. Hatıralar bedelleştirilebilinir mi oğlum? Çok güzeldi köyümüz. Buralar

${ }^{5}$ Hüseyin Ağuiçenoğlu, “Ak Toprakla Dobruca Arasında, Dobruca Müslüman Türk Basınında Hicret Konusunda Yapılan Tartı̧̧malar”, Osmanlı Araştırmaları, 22, İstanbul 2003, s. 65- 70.

\section{History Studies}


ne ki. Bir havası vardl. Bir suyu vardı! Bu duygunun oluşturduğu travmayı belki de "Hep geriye döneceğimizi düşünürdük. Kızımızl yerliye verirsek burada kalır derdik. Bu sebeple on yıl boyunca kız alıp vermedik." "Geldikten sonra memleketimize, köyümüze döneriz diye çok bekledik. Bu sene olmadl yeni sene gideriz gayri" ümidiyle atlatmışlardır. Bir mübadil "Gönderseler sabahı beklemeyiz. Akşamdan çıkar gideriz. şeklinde memleket özlemini dile getiriyor. Başka bir muhacir özlem duygusunu şu kelimelerle aktarıyor: "Oraları özlüyorum. Ama gidemiyorum. Çocukluk ve memleket rüyalarıma giriyor.". Bir mübadil de memleket hasretini şu ifadelerle dile getirmekteydi: "İstiyorum dua ediyorum. Bir kez göreyim. Sonra öleyim. Evimizi görmeye gidiyorum. Toprak getirecem. Annemin mezarına su ve toprak getirecem."

Gerçekten göç trajedilerini anlatan kaç tablo, şiir, roman ve hatta hatırat mevcuttur. Devlet bununla ilgili ne kadar vesika yayımlamıştır. Herhalde bir elin parmaklarını geçmez. Çünkü yaşanan sıkıntıları paylaşmak, anlatmak veya aktarmak Türk kamuoyu anlayışına uygun değildir. Belki de orayı unutmak adına yaşadıkları travmaları çocuklarının yaşamasına engel olmak için hatıraları, yaşanmışlıkları yazılı veya sözlü olarak gelecek kuşaklara aktarmamışlardır. Aslında Türk toplumu çekilen zorlukları, yaşanan sıkıntıları, bireysel veya toplumsal bazda gelecek kuşaklara genelde aktarmaz. Sanki unutmak ve unutturmak ister. Celal Bayar hatıratında bu yöntemi tenkit eder. Ama göç trajedileri aşağıdaki dizelerde görüleceği üzere türkülere yansımıştır.

\section{Edirne Ovasinda \\ Serpildim kaldım \\ Arçlı̆̆ım tükendi \\ Evladı sattım \\ O viran babamı \\ Yolda biraktım \\ Edirne Ovasinda \\ Nanenin kokusu \\ Cihana yeter \\ Ah şu macırlık ölümden beter ${ }^{6}$}

Diğer grup tarafından yaratılmış ve bir grupta yoğun aşağılama ve mağdur olma duygularının yaşandığı olaylara seçilmiş travma adı verilir. Ötekileştirme, vatanından ve yuvasından kovulma veya aşağılanma ve mağduriyet kişide seçilmiş travmaya sebebiyet verir. Kişi veya toplum maruz kaldığ bu olayları ikinci bir kişiye aktarmadan veya geçmişte kaybettiklerinin yasını tutmadan bu travmayı atlatamaz. Yas sürecinde kayıp kabullenilir?. Göçmen mani, türkü, ilahi, ağıt yakarak yaşadığı travmayı açığa vurur ve rahatlar ${ }^{8}$. Söz konusu sözlü ürünler biz tarihçilere de yaşanmışlıkları, göçmenin psikolojisini tespit etmesi açısından kaynaklık eder. Travmaya yol açan olaylar yaş gruplarına göre göçmenleri farklı etkiler. Orta yaş grubunda olup aileyi geçindirmekle yükümlü olanlar belirli bir iktisadi ve sosyal seviyeye ulaşana kadar çalışmanın ve kazanmanın dışında başka bir işle uğraşmaz. Eğitim çağındaki çocuk yaşanmışlıkları bilinç altına iter ve yeni şartlara uygun pozisyon alır. Okulda göçmen kimliğini ifşa etmez. Orta yaş grubu ise yalnızlaşır. Göçmen kendisi gibi olanlarla irtibat kurdukça bu sendromdan kurtulur. Zamanla bazı göçmenler terk ettiği yerin şartlarını ve göç

\footnotetext{
${ }^{6}$ Cengiz Gökçen, "Göç ve Matem”, Halk Kültüründe Göç Uluslar arası Sempozyumu Bildirileri , Ballkesir 2010; Türkiye Dışındaki Türk Edebiyatları Antolojisi, 8, Bulgaristan Türk Edebiyatı, 1997, 126.

7 Adem Sağır, "Sosyolojisi Bağlamında Göçün Sosyo-Politiği: Sovyet Rusya Örneği”. Avrasya Incelemeler Dergisi, 1/1 (2012), s. 355- 391.

${ }^{8}$ Zehra Kaderli Yapıcı, Bulgaristan Göçleri Bağlamında Türk Kadınlarının Göç Anlatıları, Yayımlanmamış Doktora Tezi, Ankara 2008.
} 
sebeplerini unutur. Göçün zorunlu olup olmadığını bile sorgulamaya başlar. Tüm olumsuzlukları geldiği yerle mukayese eder. Karşılaştığı sorunların sebebini göç etmiş olmaya bağlar. Göçmen ötekini tanımlarken farkları kendi lehine yorumlar. Göçmen deneyimini ötekine anlatarak psikolojik olarak rahatlar.

Göçmen kimliğini korumak adına göç yoluna düşer. Ancak kimlik de geride bırakılanlar arasında kalır. Artık Kırımlı, Kafkasyalı, Varnalı, Selanikli değildir. Ama Samsunlu, Trabzonlu ve İzmirli de olamamıştır. Burada yeni bir kimlik ile tanışır: Muhacir. Yerli ahali göçmenle menfaat çatışmasına girdiğinde onu ötekileştiriverir: Rum dölü, Ermeni dölü diye. Muhacir amiyane bir tabirle Türk dölü olduğu için sürülmüş, burada Rum veya Ermeni dölü oluvermiştir. Bir Bulgaristan göçmeni bu durumu şöyle tanımlıyordu: "Bize ikide bir Bulgar diyorlar. Bu çok kırıcl. Bize gavur dediler. Bulgaristan'da Türk var mıymış gavursunuz siz derlerdi. Zoruma giderdi. Ötede Türk idik. Burada gavur olduk. Başka bir muhacir de aynı konuda şu cümlelerle serzenişte bulunuyordu: "Bize Türkçeyi nerede ögrrendiniz dediler. Halbuki biz Türkoğlu Türk'üz. Osmanlı Türklerindeniz. Lisanımız Türkçe. Başka lisanımız yok". Göçmenlerin kendi aralarında da ötekileştirme var. "Biz sizin taraftan (Deliorman- Kuzey Doğu Bulgaristan) hiç kız almak istemezdik. Biz sizin tarafı daha Bulgarlaşmış bilirdik.

Giritli göçmenler ise gavur, Rum gibi ifadelerle dışlanmışlardır ${ }^{9}$. Adada sürülmesi gereken yabancı olarak tanımlanan Giritli Müslümanlar Anadolu'da da anlamadıkları bir dili kullanan yabancıydılar. Aslında Giritli göçmenler de geliş tarihlerine göre kendilerini farklı kelimelerle tanımlayabilmişlerdir. II. Abdülhamid döneminde gelen Giritli göçmenler, mübadele zamanı kendilerini yeni gelen hemşerilerinden ayrıt etmek için yerli veya eski Giritli olarak tanımladılar. Mübadele ile gelenler ise kendilerine Yeni Giritliler ismini yakıştırdılar ${ }^{10}$.

Göçün göçmen üzerinde son derece travmatik bir etki yapmasının en önemli nedeni göçmenin kimlik bunalımına sürüklenmesidir. Benlik bilincinin sağlıklı olabilmesinin en temel koşulu insanın kendisini güven içerisinde hissetmesidir. Göç güvensizlik duygusu hissettirdiği için insanları korkuyla karışık bir kimlik krizine iter. Göçmen kendisini ne terk ettiği yerin ve ne de yerleştiği yerin elemanı olarak görür. Göçmenlerin ifadesiyle ne oralıdır, ne buralıdır. Ortada bir yerde sıkışıp kalmıştır.

Bir göçmen, yerlilerin kendilerine davranış şekillerini şu cümlelerle tanımlıyordu: Yerliler Ne geldiniz buraya? diye sorarlardl. Yardım ne gezer yakacak odun bile vermezlerdi. Çalyya oduna gitsek tutarlard, hor görürlerdi bizi. İlk geldiğimiz yıllar "Macurlar adam yermiş" derlerdi. Mahalle arasında çocuklar bizleri görünce kaçarlardı. "Bitli macir" diye küçümserlerdi ${ }^{11}$.

Yerli ahali gelenleri muhacir olarak isimlendirir. Muhacir, sığınmış her türlü haktan mahrum, her türlü felakete maruz biçare, zavallı, kırmızı kuşaklı Türk demektir. Bir milletvekili mecliste konuyu şöyle gündeme getirmekteydi: Bize gelen adam Türk olmak için geliyor. Esasen Türk'tür. Muhacir demek cinayet olarak değerlendirilmektedir. Muhacir ve mülteci kavramlarının oluşturduğu psikolojik travmay yok etmek için bu kelimelerin yerine Türkçe kavramlar icat edilmelidir. Bu değişiklik talebindeki amaç öz Türkçecilik yapmak değil, muhacir kelimesinin oluşturduğu travmayı önlemektir. Bu nedenle 1923 sonrası sözleşme gereği Yunanistan'dan gelenleri yerli ahali muhacir olarak tanımlarken onlar israrla kendilerinin muhacir olmadıklarını mübadil olduklarını vurgulamaktaydılar.

\footnotetext{
${ }^{9}$ Tahmiscizade Mehmed Macid, Girid Hatıraları, Yayına Hazırlayan İsmet Miroğlu- İlhan Şahin, İstanbul 1977.

${ }^{10}$ Rüştü Çelik, Kandiye Olaylarl, Girit'in Osmanlı Devleti'nden Kopuşu, İstanbul 2012, s. 52- 70.

${ }^{11}$ Kemal Yalçın, Emanet Çeyiz Mübadele Insanlart, İstanbul 2005, s. 209.
} 
Mübadil Mehmet Sönmez kendisiyle yapılan bir mülakatta Aslında biz macir değiliz. Macir harp olur oradan kaçar. Biz kendi keyfimizle bırakıp gelmedik. Niye vatanımızı bırakalım ki. İkinci kuşak bir mübadil ise bu konuda şu değerlendirmeyi yapıyor: Bizimkilere de muhacir diyorlar. Herhalde muhacire benzediği için öyle demişler. Ben bile biraz rahatsız oluyorum. Birisi muhacir misin dediğinde tık kalbime ufak bir vurur. Zaten atalarımız mübadil. Biz değiliz aslen. Başka biri göçü yabancılaşma olarak tanımlıyor. Geldiğin yere yabancısın, dağa taşa yabancisin.

Muhacirler belki de kimlik bunalımını aşmak, yerli ahalinin ötekileştirmesine engel olmak için kendisini muhacirim, Rumeliliyim diye tanıttıktan sonra Bizimkiler Balkanlara Konya Karaman'dan gelmişler. Memlekete yerleşmişler. Biz hem Türk'üz, hem Müslüman söylemiyle Türk olduklarını ısrarla vurgulama ihtiyacı duymaktadırlar.

Göç sırasında ise bu yolculuğun ne kadar güvenli, tehlikeli ya da meşakkatli olduğu dikkate alınmalıdır. Göç sonrası dönem açısından ise göç edilen yerin özelliklerine bakılmalıdır. Göç edilen yer ne kadar kucaklayıcıysa, ne kadar az dışlayıcı ve ayrımcıysa, kayıpları telafi etmeye ne kadar müsait ise göçün olumsuz etkileri o kadar azalacaktır. Bununla beraber her göçte bir şeylerin şu ya da bu düzeyde kaybedilmesi esastır.

Bir şeyler geride bırakılmışır ve yeni baştan başlamak gerekmektedir. Kayıplar büyükse ve yeni gelinen yer göçmene dostça, destekleyici tarzda davranmıyorsa o zaman çeşitli psikolojik zorlukların gelişmesi için yeterince risk faktörü bir araya gelmiş olabilir. Bu durumlarda en sık görülen psikolojik zorluklar kaygı, depresyon ve ilişki problemleridir. Kadın, erkek, çocuk hiç bir grup bu tür sorunlara karşı bağışıklı değildir. Bu zorlukların ortaya çıkması ve bunlarla baş etme yolları kişiden kişiye değişir. Sonuç olarak yeni gelinen yerde ekonomik ve kültürel uyum ne kadar çabuk ve iyi olursa göçün yarattığı psikolojik baskının etkisi o kadar çabuk atlatılacaktır.

Devlet göçmen yerli kaynaşmasını sağlamak amacıyla Osmanlı'dan günümüze müteferrik iskân politikası uygulamıştır. Göçmenler imkânlar dâhilinde mevcut yerleşmelere iskân edilmeye çalışılmıştır. Buna karşılık göçmen karşılaştığ 1 zorluklarla baş etmenin yolunu gettolaşmada görebilmiştir.

Bunu Karabağ kaçgunlarının yaşadıklarıyla örneklendirebiliriz. Karabağ kaçgunları ile aynı binada oturan bir Azerbaycan Türkü'nün söylediklerine kulak verelim: Benim yaşadığım şehre gelip yerleşen çok sayıda kaçgun var. Kendilerini yerli halktan farkl görüyor ve onlardan uzak duruyorlardı. Yerliler de gö̧̧menleri kendi içlerine almıyorlardı. Onlara hep yabancı gibi davranıyorlardı. Her ne kadar hepimiz aynı milletin fertleri olsak da... Çocukluğumdan beri göçmenlerin içinde yaşadım. Oturduğumuz apartman sanki ikiye ayrılmıştı. Batı tarafi göçmenlerin, doğu tarafiysa bizimdi. Göçmenlerin yaşadıkları her yerde yaşam tarzı böyleydi. Ne göçmenler, ne de yerli ahali bir birlerini tam kabullenip komşuluk yapamıyorlardı. Bununla beraber nadiren çok samimi ortamlar da oluyordu. Bu örnek bize göçmenlerin müteferrik yerleştirilse bile psikolojik veya ilişkisel boyutta gettolaşabileceklerini göstermektedir. Gettolar abartılmazsa uyum sürecinin ilk adımını oluşturabilir. Zaman içinde deneye yanıla getto sınırlarının dışına çıkıp tedricen bütünleşme sağlanabilir. Ama göç edilen yer, göç edenlere karşı düşmanca ayrımcı bir tavır içindeyse, o zaman göç eden için bütünleşme değil, kendini koruma ön plana çıkar ve gettolaşma sürdürülür.

\section{Sonuç}

Bildiri ve makalelere sonuç yazılması usuldendir. Ancak bir mübadil teyze öğrencime verdiği mülakatta "Kızım senin hocan ne anlar mübadeleden" cümlesinde vurguladığ 1 gibi 
yaşamayan ne muhaciri ve ne de muhacereti anlayamaz. Belki daha iyi anlaşılmasını sağlar düşüncesiyle aşağıdaki türküyü dikkatlerinize sunarak sözlerime son vermek isterim.

Hicret edip gider Allah aşkına

Gidenlere kalan kullar ayledi

N'apsin kalan, macır dönmüs şaşkına

Arkasindan akan sular ayledi.

Kiracılar bekler dizgin elinde

Cem olmuş komşular sağında solunda

Mezarlık sokağı hicret yolunda

Dayler taşlar vatan deyip ayledi.

Ana yavrisinı birakıp gider

Kızı arkasından kuş gibi öter

Bu ayrllık bize ölümden beter

Dayler taşlar vatan deyip ayledi.

Varna'dan pindik gideriz amma

Sakın Bulgarya'da eylenip kalma

Malına güvenip kendini salma

Dayler taşlar vatan deyip ayledi.

Gece gündüz ana deyip aylerim Tesalla verip gönnümü eylerim Bu gülmedik başla acap neylerim Dayler taşlar vatan deyip ayledi.

Bu asira derler yirminci asır

Dinleyin, sözlerimde yoktur kusur

Kalmışı şu beldede biz yesir

Dayler taşlar vatan deyip ayledi.

Tüccarlarda yoktur ne insaf, ne hatır Merkezde macıra çekerler satır Burada kalanlar hepsi de fakir Dayler taşlar vatan deyip ayledi.

Kaçtı macırların beti benizi Aşıp ta giderler Karadeniz'i Ayrıldı anadan oğluyla kızı

Dayler taşlar vatan deyip ayledi.

Kalanlar döndüler boyun iyerek Yas edip te göz yaşını silerek Bu hasretlik mahşere kaldı diyerek Dayler taşlar vatan deyip ayledi.

\section{Kaynakça}

COŞAR, Mevhibe, "Bir Kıyamet Provası: Göçe Sürgün Hayatlar", Göç Dergisi,3/2, (Ekim 2016), s. 166- 174.

FINDIKOĞLU, Z. F., Türkiye'de İslav Muhacirleri (1961-1962) Türkiye'deki Malakan ve Kazakların Rusya'ya Dönmeleri, İstanbul 1966. 
Zaman, 15 Temmuz 1935, No. 385.

AĞUİÇENOĞLU, Hüseyin, "Ak Toprakla Dobruca Arasında, Dobruca Müslüman Türk Basınında Hicret Konusunda Yapılan Tartışmalar”, Osmanlı Araştırmaları, 22, İstanbul 2003, s.

GÖKÇEN, Cengiz, "Göç ve Matem”, Halk Kültüründe Göç Uluslar arası Sempozyumu Bildirileri, Balıkesir 2010.

Türkiye Dışındaki Türk Edebiyatları Antolojisi, 8, Bulgaristan Türk Edebiyatı, 1997.

SAĞIR, Adem, "Sosyolojisi Bağlamında Göçün Sosyo-Politiği: Sovyet Rusya Örneği”. Avrasya Incelemeler Dergisi, 1/1 (2012), s. 355- 391.

YAPICI, Zehra Kaderli, Bulgaristan Göçleri Bağlamında Türk Kadınlarının Göç Anlatıları, Yayımlanmamış Doktora Tezi, Ankara 2008.

Tahmiscizade Mehmed Macid, Girid Hatıraları, Yayına Hazırlayan İsmet Miroğlu- İlhan Şahin, İstanbul 1977.

ÇELİK, Rüştü Kandiye Olaylarl, Girit'in Osmanlı Devleti'nden Kopuşu, İstanbul 2012.

YALÇIN, Kemal Emanet Çeyiz Mübadele İnsanları, İstanbul 2005. 